\title{
Occurrence of the viruses belonging to the Allexivirus genus on garlic plants in Poland
}

\author{
Występowanie wirusów z rodzaju Allexivirus na roślinach czosnku w Polsce
}

\author{
Maria Chodorska, Elżbieta Paduch-Cichal, Elżbieta Kalinowska, Marek S. Szyndel
}

\begin{abstract}
Summary
Garlic (Allium sativum L.) can be infected by numerous viruses that are spread by the seed bulbs during the vegetative propagation of the plants. Eight garlic viruses that belong to the Allexivirus genus are transmitted by mites. The aim of this study was to detect and identify Allexiviruses infecting garlic in Poland. Identification of Garlic virus A (GarV-A), Garlic virus B (GarV-B), Garlic virus C (GarV-C) and Shallot virus $X$ (ShVX) was based on ELISA (Enzyme-Linked Immunosorbent Assay) and confirmed by RT-PCR (Reverse Transcription Polymerase Chain Reaction). Garlic virus D (GarV-D), Garlic virus E (GarV-E) and Garlic virus X (GarV-X) were detected using RT-PCR. The samples of garlic plants were collected in September 2011 and July 2012 from garlic production field located in different part of Poland. Garlic virus $D$, Garlic virus $X$ and Garlic virus $B$ were the most abundant garlic viruses in all examined regions and were identified in 84, 67 and $54 \%$ of all samples, respectively. Garlic virus $A$ and Garlic virus $C$ were detected in all studied regions with low frequency. None of the tested garlic samples were infected with Shallot virus $X$. Allexiviruses that were present in garlic plants occurred always in mixed infections.
\end{abstract}

Key words: garlic plants, Allexiviruses, ELISA, RT-PCR

\section{Streszczenie}

Rośliny czosnku mogą być porażane przez wiele gatunków wirusów. Wirusy infekujące czosnek rozprzestrzeniają się wraz z materiałem rozmnożeniowym. Ponadto osiem gatunków należących do rodzaju Allexivirus jest przenoszonych przez szpeciele. Celem przeprowadzonych badań było wykrywanie i identyfikacja allexiwirusów infekujących rośliny czosnku w Polsce. Obecność wirusa $A$ czosnku, wirusa B czosnku, wirusa C czosnku i wirusa X szalotki stwierdzano przy pomocy testu serologicznego ELISA (Enzyme-Linked Immunosorbent Assay) i potwierdzano techniką RT-PCR (Reverse Transcription Polymerase Chain Reaction). Wirus D czosnku, wirus E czosnku i wirus $X$ czosnku były wykrywane przy użyciu techniki RT-PCR. Próbki materiału roślinnego pobierano w dwóch terminach, we wrześniu 2011 roku oraz w lipcu 2012 roku, z pól produkcyjnych, zlokalizowanych w różnych rejonach Polski. Najczęściej występującymi wirusami w polskich uprawach czosnku był wirus D czosnku, wirus X czosnku i wirus B czosnku (84, 67 i 54\%). Wirus A czosnku i wirus $C$ czosnku były wykrywane we wszystkich badanych regionach, jednak ze znacznie niższą częstotliwością występowania. Żadna $z$ badanych prób nie była porażona przez wirus $X$ szalotki. Allexiwirusy w roślinach czosnku występowały zawsze $w$ mieszanych infekcjach.

Słowa kluczowe: rośliny czosnku, allexiwirusy, ELISA, RT-PCR

\footnotetext{
Szkoła Główna Gospodarstwa Wiejskiego w Warszawie

Samodzielny Zakład Fitopatologii

Nowoursynowska 159, 02-776 Warszawa

maria_chodorska@sggw.pl
} 


\section{Wstęp / Introduction}

Czosnek pospolity (Allium sativum L.) należy do rodziny liliowate (Liliaceae), rzędu liliowce (Liliales). Czosnek jest znany od około 5 tysięcy lat i obecnie jest uprawiany w większości rejonów świata, zwłaszcza na terenie Chin i Indii oraz w krajach basenu Morza Śródziemnego (Hiszpania, Francja, Egipt, Turcja), w Ameryce Południowej (Argentyna, Brazylia), Ameryce Północnej (Meksyk, USA), Korei Południowej i Rosji. W Polsce produkcja czosnku utrzymuje się na poziomie około 15-20 tys. ton i prowadzona jest na powierzchni około 3 tys. ha, głównie na obszarze województw: łódzkiego, mazowieckiego, małopolskiego i pomorskiego. Czosnek, dzięki swoim właściwościom, może być wykorzystywany jako najsilniej działający antybiotyk, a także może być traktowany jako źródło związków przeciwnowotworowych. Wyciagi z czosnku obniżają poziom cholesterolu we krwi oraz zapobiegają nadciśnieniu i miażdżycy.

$\mathrm{Na}$ roślinach czosnku można obserwować choroby powodowane przez wirusy należące do rodziny Potyviridae (rodzaj Potyvirus), Betaflexiviridae (rodzaj Carlavirus) i Alphaflexiviridae (rodzaj Allexivirus) (King i wsp. 2011). Ponieważ są to wirusy o zbliżonych cechach morfologicznych i często podobnej biologii, dlatego istnieją trudności w rozdzieleniu tych wirusów. Poty- i carlawirusy izolowane $\mathrm{z}$ roślin czosnku są patogenami polifagicznymi, natomiast allexiwirusy porażają $\mathrm{w}$ naturze jedynie rośliny należące do rodzaju Allium. Wirusy te, mimo iż były wykryte $w$ latach dziewięćdziesiątych 20. wieku, zostały uznane za osobny rodzaj dopiero w 2000 roku (Regenmortel van i wsp. 2000). Stanowią jedno $\mathrm{z}$ poważniejszych zagrożeń $\mathrm{w}$ uprawie czosnku ze względu na rozprzestrzenianie się wraz $z$ materiałem rozmnożeniowym, co sprawia, że wystąpienie na krajowych plantacjach staje się bardziej prawdopodobne. Ponadto, w okresie wegetacji i podczas przechowywania cebul, mogą być przenoszone przez wektora, jakim jest szpeciel Aceria tulipae. Zgodnie z danymi zawartymi w IX Raporcie ICTV (International Committee on Taxonomy of Viruses) (King i wsp. 2011) do rodzaju Allexivirus zaliczono następujące gatunki wirusów: przenoszony przez szpeciele nitkowaty wirus czosnku (Garlic mite-borne filamentous virus, GarMbFV), wirus A czosnku (Garlic virus $A$, GarV-A), wirus B czosnku (Garlic virus B, GarV$\mathrm{B}$ ), wirus C czosnku (Garlic virus $C$, GarV-C), wirus D czosnku (Garlic virus D, GarV-D), wirus E czosnku (Garlic virus E, GarV-E), wirus X czosnku (Garlic virus $X$, GarV-X) oraz wirus X szalotki (Shallot virus $X$, ShVX). Obecność allexiwirusów w roślinach czosnku jest przyczyną obniżenia plonu cebul, zwłaszcza ich ciężaru (od 14 do $32 \%$ ) i zmniejszenia ich średnicy (od 6 do 11\%). Szkodliwość tych wirusów wyraźnie zwiększa się, gdy czosnek porażony jest równocześnie przez inne wirusy (25-43\%) (Cafrune i wsp. 2006).

Dotychczasowe badania dotyczące allexiwirusów prowadzone były na szeroką skalę w krajach azjatyckich, gdzie ich obecność stwierdzono w roślinach rosnących na terenie Chin, Japonii i Korei. Badania prowadzone na terenie Europy, we Francji (Lot i wsp. 1998), Grecji
(Dovas i wsp. 2001) i na terenie Czech (Klukáčková i wsp. 2004; Smékalová i wsp. 2010) wykazały występowanie różnych gatunków wirusów z rodzaju Allexivirus. W Polsce wstępne badania nad występowaniem allexiwirusów przeprowadzono w 2012 roku (Chodorska i wsp. 2012).

Celem przeprowadzonych badań było wykrywanie i identyfikacja siedmiu gatunków wirusów porażających rośliny czosnku należących do rodzaju Allexivirus, tj. GarV-A, GarV-B, GarV-C, GarV-D, GarV-E, GarV-X oraz ShVX w roślinach czosnku pochodzących z 19 pól produkcyjnych zlokalizowanych w 4 województwach: łódzkim, małopolskim, mazowieckim i pomorskim przy użyciu testu immunoenzymatycznego - ELISA (EnzymeLinked Immunosorbent Assay) oraz przy pomocy reakcji odwrotnej transkrypcji i następującej po niej amplifikacji jej produktu - RT-PCR (Reverse Transcription Polymerase Chain Reaction).

\section{Materiały i metody / Materials and methods}

Badania prowadzono w latach 2011-2012, w Katedrze Fitopatologii Szkoły Głównej Gospodarstwa Wiejskiego w Warszawie. Materiał roślinny (cebule i liście) pobierano we wrześniu 2011 roku oraz w lipcu 2012 roku z 19 pól produkcyjnych zlokalizowanych w rejonach o największej koncentracji upraw czosnku, tj. w województwie łódzkim, małopolskim, mazowieckim i pomorskim. Łącznie pobrano i przetestowano 256 prób.

Rośliny były badane przy użyciu testu serologicznego ELISA $\mathrm{z}$ wykorzystaniem przeciwciał specyficznych przeciwko wirusowi A czosnku, wirusowi B czosnku, wirusowi C czosnku oraz wirusowi $\mathrm{X}$ szalotki (Leibniz Institute DSMZ-German Collection of Microorganisms and Cell Cultures, Niemcy). Pojedynczą próbę stanowiło $0,500 \mathrm{~g}$ tkanki roślinnej pobranej $\mathrm{z}$ cebuli lub liści czosnku, którą ucierano $\mathrm{w}$ buforze fosforanowym zawierającym $2 \%$ poliwinylopirolidonu (polyvinylpyrrolidone, PVP) oraz 0,2\% albuminy kurzej w stosunku 1:10 $(w / v)$. Dalsze procedury przeprowadzono zgodnie $\mathrm{z}$ załączoną instrukcją. Jako wartość progową absorbancji przyjęto wartość 0,200 . Dla prób kontrolnych wartość absorbancji nie przekraczała wartości 0,200.

Ekstrakcję całkowitego RNA (kwasy rybonukleinowe) $\mathrm{z}$ materiału roślinnego przeprowadzono $\mathrm{z}$ użyciem Spectrum $^{\text {TM }}$ Plant Total RNA Kit (Sigma) zgodnie z załączoną instrukcją. Przy pomocy techniki RT-PCR z wykorzystaniem specyficznych par starterów (zaprojektowane startery własne) (tab. 1) oraz zestawu do odwrotnej transkrypcji Transcriptor One-Step RT-PCR Kit (Roche, Niemcy) powielano fragmenty sekwencji genu kodującego białko płaszcza (coat protein gen, CP) oraz genu kodującego białko wiążące kwasy nukleinowe (nucleic acid binding protein gen, NABP) wirusa A czosn$\mathrm{ku}$, wirusa $\mathrm{B}$ czosnku, wirusa $\mathrm{C}$ czosnku oraz wirusa $\mathrm{D}$ czosnku, zaś w celu wykrywania i identyfikacji wirusa $\mathrm{E}$ czosnku, wirusa $\mathrm{X}$ czosnku oraz wirusa $\mathrm{X}$ szalotki zaprojektowano pary starterów obejmujące fragment genu kodującego białko replikazy (replicase protein gen). 
Tabela 1. Startery zastosowane w reakcji RT-PCR specyficzne do fragmentów genomu GarV-A, GarV-B, GarV-C, GarV-D, GarV-E, GarV-X oraz ShVX

Table 1. RT-PCR pairs of primers specific to the segment of the GarV-A, GarV-B, GarV-C, GarV-D, GarV-E, GarV-X and ShVX genome

\begin{tabular}{|c|c|c|c|c|}
\hline $\begin{array}{l}\text { Wirus } \\
\text { Virus }\end{array}$ & $\begin{array}{l}\text { Starter } \\
\text { Primer }\end{array}$ & $\begin{array}{l}\text { Sekwencja nukleotydowa } \\
\text { Nucleotide sequence }\end{array}$ & $\begin{array}{c}\mathrm{T}_{\mathrm{m}} \\
{\left[{ }^{\circ} \mathrm{C}\right]}\end{array}$ & $\begin{array}{c}\text { Temperatura przyłączania } \\
\text { Annealing temperature } \\
{\left[{ }^{\circ} \mathrm{C}\right]}\end{array}$ \\
\hline \multirow{2}{*}{ GarV-A } & ACPF & 5'-ATGTCGAATCCAACTCAGTCG-3' & 52,4 & \multirow{2}{*}{52} \\
\hline & ACPR & 5'-AGACCATGTTGGTGGCGCG-3' & 55,4 & \\
\hline \multirow{2}{*}{ GarV-B } & $\mathrm{BCPF}$ & 5'-TGACGGGCAAACAGCAGAATAA-3' & 53 & \multirow{2}{*}{50} \\
\hline & BCPR & 5'-ATATAGCTTAGCGGGTCCTTC-3' & 52,4 & \\
\hline \multirow{2}{*}{ GarV-C } & $\mathrm{CCPF}$ & 5'-TTGCTACCACAATGGTTCCTC-3' & 52,4 & \multirow{2}{*}{51} \\
\hline & CCPR & 5'-TACTGGCACGAGTTGGGAAT-3' & 51,8 & \\
\hline \multirow{2}{*}{ GarV-D } & DCPF & 5'-AAGGAGCTACACCGAAGGAC-3' & 53,8 & \multirow{2}{*}{52} \\
\hline & DCPR & 5'-TAAAGTCGTGTGGATGCATCAGA-3' & 53,5 & \\
\hline \multirow{2}{*}{ GarV-E } & EF2 & 5'-TTGCTAGACCACCTCAGTATTGAGAA-3' & 56,4 & \multirow{2}{*}{55} \\
\hline & ER2 & 5'-TAT TGG GCG TAC ATC GGT GAC TGT-3' & 57,4 & \\
\hline \multirow{2}{*}{ GarV-X } & $\mathrm{XF}$ & 5'- GCGGTAATATCTGACACGCTCCA-3' & 57,1 & \multirow{2}{*}{55} \\
\hline & $\mathrm{XR}$ & 5'-ACGTTAGCTTCACTGGGGTAGAATAT-3' & 56,4 & \\
\hline \multirow{2}{*}{ ShVX } & ShVXF & 5'-ACCGAAATCACAGTTAACTCCTTTGG-3' & 56,4 & \multirow{2}{*}{54} \\
\hline & ShVXR & 5'-TCTACGGTTGTCGATTTTGTGCGT-3' & 55,7 & \\
\hline
\end{tabular}

Reakcję RT-PCR przeprowadzono w termocyklerze 2720 (Applied Biosystems, USA) według następującego profilu termicznego $-30 \mathrm{~min} w 50^{\circ} \mathrm{C}, 7 \mathrm{~min} \mathrm{w} 94^{\circ} \mathrm{C}, 35$ cykli w $94^{\circ} \mathrm{C}$ przez $10 \mathrm{~s}, \mathrm{~T}_{\mathrm{m}}{ }^{\circ} \mathrm{C}$ (tab. 1) przez $30 \mathrm{~s}, 68^{\circ} \mathrm{C}$ przez $45 \mathrm{~s}$ oraz końcowe wydłużanie łańcucha $\mathrm{w} 68^{\circ} \mathrm{C}$ przez $7 \mathrm{~min}$. Do mieszaniny reakcyjnej dodawano $\sim 25 \mathrm{ng}$ wyizolowanego RNA. Rozdział elektroforetyczny produktów RT-PCR prowadzono $\mathrm{w}$ buforze TBE (Tris-boranEDTA) na $1,2 \%$ żelu agarozowym przy napięciu $80 \mathrm{~V}$ przez okres 40 minut w aparacie do elektroforezy poziomej Easy Cast ${ }^{\mathrm{TM}}$ Horizontal System model B1A (Owl Separation Systems, USA). Wyniki rozdziału wizualizowano na transiluminatorze UV korzystając $\mathrm{z}$ systemu dokumentacji i analizy obrazu InGenius (Syngen, Polska).
Wielkość uzyskiwanych produktów RT-PCR ustalano wobec markera GeneRuler ${ }^{\mathrm{TM}}$ DNA Ladder (Fermentas, Litwa).

\section{Wyniki i dyskusja / Results and discussion}

$\mathrm{Na}$ większości roślin czosnku obserwowano objawy w postaci mozaiki, żółtej smugowatości oraz żółtej pasiastości na liściach.

$\mathrm{Na}$ podstawie wyników przeprowadzonych testów serologicznych ELISA oraz wyników RT-PCR, najczęściej występującymi wirusami $\mathrm{w}$ testowanych próbach pochodzących $\mathrm{z}$ badanych nasadzeń produkcyjnych czosnku

Tabela 2. Występowanie wirusów w uprawach czosnku, w różnych regionach Polski

Table 2. Incidence of viruses in garlic crops, in different regions of Poland

\begin{tabular}{l|c|c|c|c|c|c|c|c}
\hline \multicolumn{1}{c|}{$\begin{array}{c}\text { Województwo } \\
\text { Province }\end{array}$} & $\begin{array}{c}\text { Liczba } \\
\text { pobranych } \\
\text { prób } \\
\text { Number of } \\
\text { samples }\end{array}$ & $\begin{array}{c}\text { GarV-A } \\
{[\%]}\end{array}$ & $\begin{array}{c}\text { GarV-B } \\
{[\%]}\end{array}$ & $\begin{array}{c}\text { GarV-C } \\
{[\%]}\end{array}$ & $\begin{array}{c}\text { GarV-D } \\
{[\%]}\end{array}$ & $\begin{array}{c}\text { GarV-E } \\
{[\%]}\end{array}$ & $\begin{array}{c}\text { GarV-X } \\
{[\%]}\end{array}$ & $\begin{array}{c}\text { ShVX } \\
{[\%]}\end{array}$ \\
\hline $\begin{array}{l}\text { Lódzkie } \\
\text { Łódź province }\end{array}$ & 50 & 58 & 64 & 22 & 40 & 20 & 40 & 0 \\
\hline $\begin{array}{l}\text { Małopolskie } \\
\text { Małopolskie province }\end{array}$ & 115 & 20 & 45 & 10 & 94,74 & 50 & 95 & 0 \\
\hline $\begin{array}{l}\text { Mazowieckie } \\
\text { Mazovia province }\end{array}$ & 50 & 9,09 & 20 & 9,09 & 100 & 100 & 33 & 0 \\
\hline $\begin{array}{l}\text { Pomorskie } \\
\text { Pomerania province }\end{array}$ & 41 & 20 & 87,50 & 11,76 & 100 & 33 & 100 & 0 \\
\hline $\begin{array}{l}\text { Razem } \\
\text { Total }\end{array}$ & 256 & 26,77 & 54,12 & 13,21 & 83,68 & 50,75 & 67 & 0 \\
\hline
\end{tabular}


były: GarV-D, GarV-X i GarV-B. Wirus A czosnku i wirus $\mathrm{C}$ czosnku zostały zidentyfikowane we wszystkich rejonach Polski objętych badaniami, jednak były wykrywane ze znacznie niższą częstotliwością niż pozostałe gatunki należące do rodzaju Allexivirus. Rośliny czosnku rosnące na polach produkcyjnych zlokalizowanych w województwie mazowieckim i pomorskim były całkowicie (100\%) porażone przez odpowiednio, GarV-D i GarV-E oraz GarV-D i GarV-X. W testowanym materiale roślinnym nie wykryto wirusa $\mathrm{X}$ szalotki przy pomocy testu serologicznego ELISA. Negatywny wynik testu został również potwierdzony techniką RT-PCR (tab. 2).

W większości badanych prób, allexiwirusy występowały w mieszanych infekcjach (tab. 3). Najczęstszą kombinacją wirusów w próbie było jednoczesne występowanie wirusa D czosnku, wirusa X czosnku i wirusa B czosnku. Równie często w jednej roślinie czosnku oprócz trzech wymienionych wirusów występował także wirus E czosnku.

Obecność wirusa A czosnku, wirusa B czosnku i wirusa $\mathrm{C}$ czosnku została potwierdzona przy użyciu techniki RT-PCR. Wynikiem elektroforezy, przeprowadzonej na $1,2 \%$ żelu agarozowym były produkty reakcji RT-PCR wielkości około 444 pz dla GarV-A, 576 pz dla GarV-B i 679 pz dla GarV-C, obejmujące fragment genu kodu-

jącego CP i NABP badanych wirusów. Produkty spodziewanej wielkości otrzymano dla prób pozytywnych w teście serologicznym ELISA. Na żelu nie obserwowano produktów reakcji dla kontroli negatywnej, uzyskanej ze zdrowych roślin czosnku (rys. 1).

Tabela 3. Procent mieszanych infekcji gatunków z rodzaju Allexivirus $\mathrm{w}$ roślinach czosnku

Table 3. Percent of multiple infections of allexiviruses in garlic plants

\begin{tabular}{l|c}
\hline \multicolumn{1}{c|}{$\begin{array}{c}\text { Liczba wirusów w próbie } \\
\text { Number of viruses in sample }\end{array}$} & {$[\%]$} \\
\hline $\begin{array}{l}\text { Dwa gatunki wirusów } \\
\text { Two viruses }\end{array}$ & 6,25 \\
\hline $\begin{array}{l}\text { Trzy gatunki wirusów } \\
\text { Three viruses }\end{array}$ & 51,61 \\
\hline $\begin{array}{l}\text { Cztery gatunki wirusów } \\
\text { Four viruses }\end{array}$ & 32,71 \\
\hline $\begin{array}{l}\text { Pięć gatunków wirusów } \\
\text { Five viruses }\end{array}$ & 6,45 \\
\hline
\end{tabular}

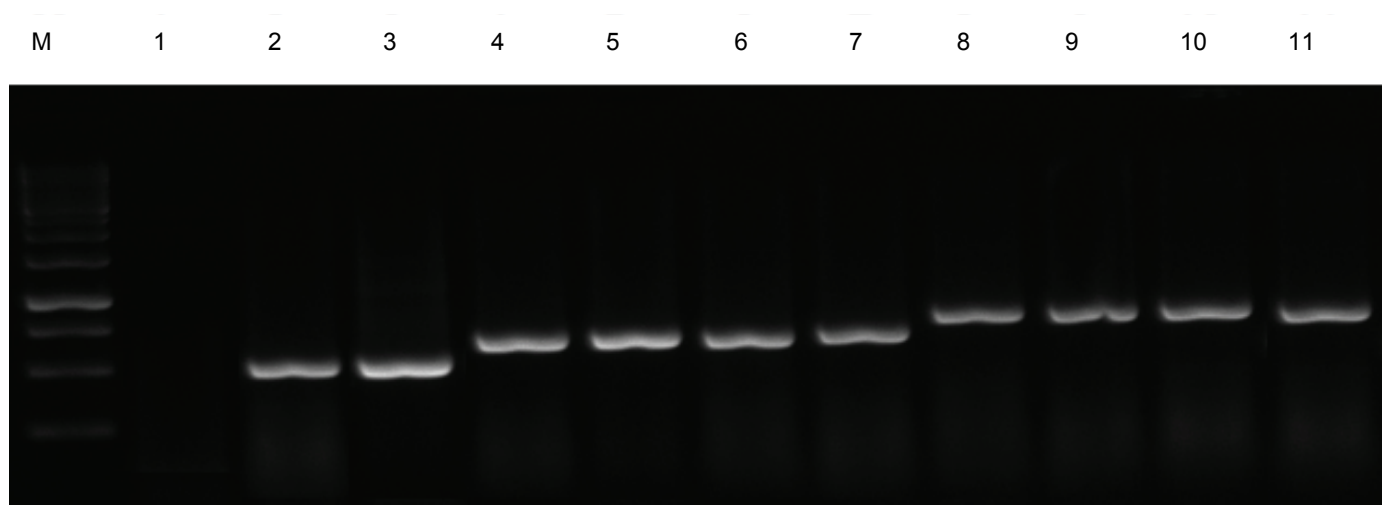

Rys. 1. Rozdział elektroforetyczny amplikonów GarV-A, GarV-B i GarV-C otrzymanych przy użyciu techniki RT-PCR

$\mathrm{M}$ - marker (GeneRuler ${ }^{\mathrm{TM}} 1 \mathrm{~kb}$ DNA Ladder, Fermentas), 1 - kontrola negatywna, 2-3 - próby zainfekowane GarV-A (444 pz), 4-7 - próby zainfekowane GarV-B (576 pz), 8-11 - próby zainfekowane GarV-C (679 pz)

Fig. 1. Agarose gel analysis of GarV-A, GarV-B and GarV-C amplicons obtained by RT-PCR tests

$\mathrm{M}$ - GeneRuler ${ }^{\mathrm{TM}} 1 \mathrm{~kb}$ DNA Ladder (Fermentas), 1 - negative control, 2-3 - samples infected with GarV-A (444 bp), 4-7 - samples infected with GarV-B (576 bp), 8-11 - samples infected with GarV-C (679 bp)

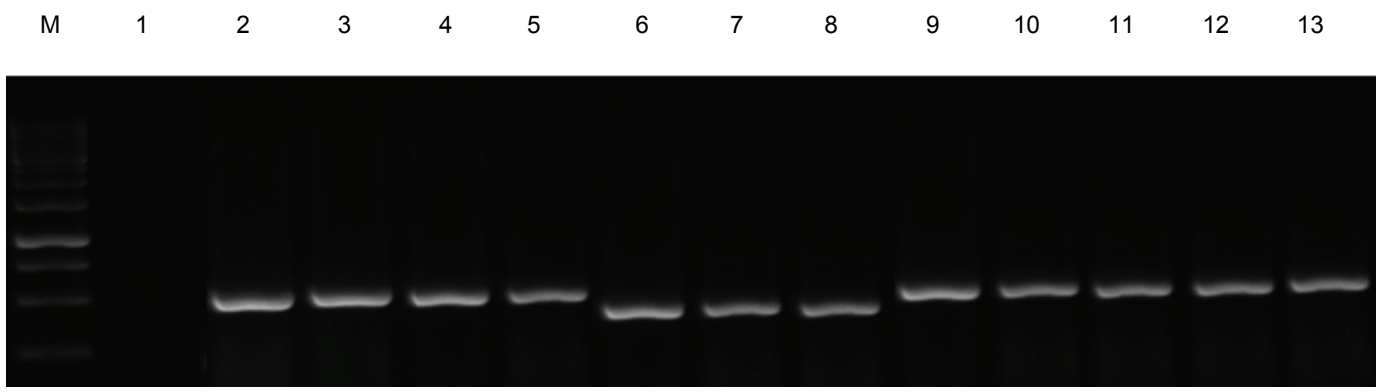

Rys. 2. Rozdział elektroforetyczny amplikonów GarV-D, GarV-E i GarV-X otrzymanych przy użyciu techniki RT-PCR

$\mathrm{M}$ - marker (GeneRuler ${ }^{\mathrm{TM}} 1 \mathrm{~kb}$ DNA Ladder, Fermentas), 1 - kontrola negatywna, 2-5 - próby zainfekowane GarV-D (456 pz), 6-8 - próby zainfekowane GarV-X (386 pz), 9-13 - próby zainfekowane GarV-E (458 pz)

Fig. 2. Agarose gel analysis of GarV-D, GarV-E and GarV-X amplicons obtained by RT-PCR tests

$\mathrm{M}$ - GeneRuler ${ }^{\mathrm{TM}} 1 \mathrm{~kb}$ DNA Ladder (Fermentas), 1 - negative control, 2-5 - samples infected with GarV-D (456 bp), 6-8 - samples infected with GarV-X (386 bp), 9-13 - samples infected with GarV-E (458 bp) 
Startery zaprojektowane na podstawie pełnych sekwencji GarV-D, GarV-E i GarV-X dostępnych w banku genów okazały się skuteczne do wykrywania tych wirusów przy pomocy techniki RT-PCR. Analiza elektroforetyczna produktów RT-PCR wykazała obecność produktów reakcji o oczekiwanej wielkości dla wszystkich badanych wirusów (rys. 2).

Poziom porażenia roślin czosnku przez wirusy w Polsce jest wysoki ze względu na wegetatywny sposób rozmnażania tej rośliny. Producenci wykorzystują nie sprzedany materiał roślinny jako materiał rozmnożeniowy w kolejnym sezonie wegatycyjnym, stąd koncentracja wirusów w tych roślinach zwiększa się z roku na rok. Dodatkowe przenoszenie wirusów należących do rodzaju Allexivirus przez szpeciela (A. tulipae) zwiększa ryzyko masowego porażenia roślin czosnku. Występowanie allexiwirusów w roślinach czosnku, które zostały wykryte podczas badań przedstawionych w niniejszym artykule są przyczyną objawów obserwowanych na liściach czosnku w postaci mozaiki, deformacji i żółtych smugowatości (Yamashita i wsp. 1996).

Rozpoznanie zagrożenia upraw czosnku przez allexiwirusy, ustalenie zmienności w populacji tych wirusów, może mieć istotne znaczenie przy podejmowaniu decyzji dotyczących ochrony upraw czosnku przed tymi patogenami oraz w hodowli odpornościowej nowych polskich odmian czosnku, dlatego planowana jest kontynuacja przedstawionych badań

\section{Wnioski / Conclusions}

1. Allexiwirusy stanowią poważne zagrożenie upraw czosnku w Polsce.

2. Rośliny czosnku uprawiane na polach produkcyjnych zlokalizowanych na terenie województwa łódzkiego były najbardziej narażone na infekcje przez GarV-B i GarV-A, małopolskiego - GarV-X i GarV-D, mazowieckiego - GarV-D i GarV-E oraz pomorskiego GarV-D, GarV-X i GarV-B.

3. Wirusy w roślinach czosnku występują zawsze w mieszanych infekcjach.

4. Użyte (zaprojektowane startery własne) startery okazały się przydatne do wykrywania: GarV-A, GarV-B, GarV-C, GarV-D, GarV-E i GarV-X w roślinach czosnku.

\section{Literatura / References}

Cafrune E.E., Balzarini M., Conci V.C. 2006. Changes in the concentration of an allexivirus during the crop cycle of two garlic cultivars. Plant Dis. 90 (10): 1293-1296.

Chodorska M., Nowak P., Szyndel M.S., Paduch-Cichal E., Sala-Rejczak K. 2012. First report of Garlic virus A, Garlic virus B and Garlic virus C in garlic in Poland. J. Plant Pathol. 94: S4.100.

Dovas C.I., Hatziloukas E., Salomon R., Barg E., Shiboleth Y., Katis N.I. 2001. Incidence of viruses infecting Allium spp. in Greece. Phytopathology 149: 1-7.

King A.M.Q., Adams M.J., Carstens E.B., Lefkowitz E.J. 2011. Ninth Report of the International Committee on Taxonomy of Viruses. Elsevier Academic Press, San Diego, USA: 905-907.

Klukáčková J., Navrátil N., Veselá M., Havránek P., Šafářová D. 2004. Occurrence of garlic viruses in the Czech Republic. Acta Fytotechnica et Zootechnica 7: 126-128.

Lot H., Chovelon V., Souche S., Delecolle B. 1998. Effects of Onion yellow dwarf and Leek yellow stripe viruses on symptomatology and yield loss of three French garlic cultivars. Plant Dis. 82: 1381-1385.

Regenmortel van M.H.V., Fauquet C.M., Bishop D.H.L., Carstens E.B., Estes M.K. 2000. Virus Taxonomy: 7th Report of the International Committee on Taxonomy of Viruses. Academic Press. San Diego: 981-984.

Smékalová K., Stavlíková H., Dusek K. 2010. Distribution of viruses in the garlic germplasm collectionof the Czech Republic. J. Plant Pathol. 92 (1): 273-274.

Yamashita K., Sakai J., Hanada K. 1996. Characterization of a new virus from garlic (Allium sativum L.), garlic mite borne mosaic virus. Ann. Phytopathol. Soc. Jpn. 62: 483-489. 